\title{
THE EFFECT OF THE FORMATION OF AN ARTERIOVENOUS FISTULA UPON BLOOD VOLUME ${ }^{1}$
}

\author{
BY FRANKLIN H. EPSTEIN 2 AND THOMAS B. FERGUSON \\ (From the Department of Cardiorespiratory Disease, Army Medical Service Graduate School, \\ Washington, D. C., and the Department of Medicine, Yale University School of \\ Medicine, New Haven, Conn.)
}

(Submitted for publication September 13, 1954; accepted November 10, 1954)

The creation of a large peripheral arteriovenous fistula results in a series of related physiologic adjustments, including changes in cardiac output, intravascular and intracardiac pressures, blood flow to peripheral organs and urinary excretion of water and electrolytes (1-3). The changes in blood volume which occur under these circumstances have been the subject of controversy, partly because observations made before and after surgical extirpation of a fistula are necessarily complicated by the effects of a major operation and the patient's convalescence.

Previous efforts to resolve this question have utilized protein-binding dyes such as T-1824 or Brilliant Vital Red to measure blood volume. However, the accuracy of $\mathrm{T}-1824$ as a measure of total blood volume is open to question (4) and its validity as an index to the intravascular volume of plasma in certain conditions has been challenged $(5,6)$. For these reasons it was decided to reinvestigate the early effect of an experimental arteriovenous fistula upon blood volume, and to use labelled red cells as well as T-1824 in an attempt to measure by independent methods changes in the volume of red cells and plasma.

\section{METHODS}

Seven trained mongrel dogs, weighing 10 to 18 kilograms, were fed a standard meal diet to which raw meat and ferrous sulfate were added. After control measurements of blood volume in the unanesthetized, fasting state, an arteriovenous fistula approximately one $\mathrm{cm}$. long was created surgically between the abdominal aorta and the inferior vena cava, halfway between the renal vessels and the bifurcation. From two to six weeks after the operation, the blood volume was remeasured.

Five cc. of the dog's own blood were incubated at room temperature for 30 minutes with $\mathrm{P}^{30}$. After labelling, the red cells were washed three times with cold

1 Presented in part before the American Federation for Clinical Research, Atlantic City, New Jersey, May 1953.

2 Present address: Department of Medicine, Yale University School of Medicine, New Haven, Connecticut. saline and reinjected intravenously from a calibrated syringe. Supernatant saline from the last wash contained less than 2 per cent of the total radioactivity incorporated in the red cells. The injection of cells was immediately followed by the intravenous injection of 10 mgm. of Evans Blue dye (T-1824). Heparinized samples of arterial blood were drawn at five-minute intervals for 30 minutes. Radioactivity of whole blood was measured by the method of Reeve and Veall (7). Optical density of plasma diluted with an equal volume of saline was recorded at $610 \lambda$ using a Coleman Jr. spectrophotometer. Concentrations of radioactivity in blood and of T-1824 in plasma were plotted on a semilogarithmic scale against time and the straight lines of best fit were extrapolated to the times of injection $\left(T_{0}\right)$. Hematocrit of arterial blood was determined by spinning $100 \mathrm{~mm}$. columns of blood in Wintrobe tubes in duplicate for one hour at $3000 \mathrm{rpm}$. in a centrifuge head of $15 \mathrm{~cm}$. radius from the center of the spindle to the bottom of the hematocrit tube. A correction of 0.96 was applied for plasma trapping. The following calculations were used:

$P$ s

1) Total Blood Volume (TBV P*)

$$
=\frac{\text { Radioactivity injected }}{\text { Radioactivity of } 1 \mathrm{cc} \text {. arterial blood at } \mathrm{T}_{0}}
$$

2) RBC Volume (RBC $P \approx$ )

$=\left(\mathrm{TBV} \mathrm{P}^{\mathrm{x}}\right) \times$ Arterial Hematocrit $\times 0.96$

$T-1824$

3) $\mathrm{T}-1824$ space $=\frac{\mathrm{T}-1824 \text { injected }}{\mathrm{T}-1824 \text { in } 1 \mathrm{cc} \text {. arterial plasma at } \mathrm{T}_{\mathrm{o}}}$

4) Total Blood Volume (TBV T-1824)

\section{Combined}

T-1824 space

$=\frac{1-(\text { Arterial Hematocrit } \times 0.96)}{1-10}$

5) Total Blood Volume (TBV comb)

$$
=\left(\mathrm{RBC} \mathrm{P}^{22}\right)+\mathrm{T}-1824 \text { space }
$$

6) Total Body Hematocrit (TB Hct) $=\frac{(\text { RBC P }}{\text { (TBV comb) }}$

RESULTS

\section{General}

(Table I)

Following the operation, cardiac filling pressure was chronically elevated and the cardiac output increased. Cardiac output could not be increased 
TABLE I

\begin{tabular}{|c|c|c|c|c|c|c|c|c|c|c|c|}
\hline \multirow[b]{2}{*}{ Dog } & \multirow{2}{*}{$\begin{array}{c}\text { Days } \\
\text { before } \\
\text { or after } \\
\text { fistula }\end{array}$} & \multirow[b]{2}{*}{ wt. } & \multicolumn{2}{|c|}{$\mathrm{P}^{2}$} & \multicolumn{2}{|c|}{ T-1824 } & \multirow[b]{2}{*}{$\begin{array}{c}\text { TBV } \\
\text { comb }\end{array}$} & \multirow[b]{2}{*}{$\begin{array}{c}\text { Arterial } \\
\text { het }\end{array}$} & \multirow[b]{2}{*}{$\begin{array}{c}\mathbf{T B} \\
\text { hct }\end{array}$} & \multirow{2}{*}{$\frac{\text { TB het }}{\text { Arterial hct }}$} & \multirow[b]{2}{*}{$\begin{array}{l}\text { Edema/ / } \\
\text { Ascites }\end{array}$} \\
\hline & & & $\begin{array}{l}\text { RBC } \\
\text { vol. }\end{array}$ & TBV & $\begin{array}{c}\text { Plasma } \\
\text { vol. }\end{array}$ & TBV & & & & & \\
\hline 1 & $\begin{array}{l}-6 \\
+33\end{array}$ & $\begin{array}{c}k g . \\
12.5 \\
11.8\end{array}$ & $\begin{array}{c}c c . \\
329 \\
345\end{array}$ & $\begin{array}{l}c c . \\
851 \\
983\end{array}$ & $\begin{array}{l}c c . \\
582 \\
801\end{array}$ & $\begin{array}{c}c c . \\
948 \\
1,234\end{array}$ & $\begin{array}{c}c c . \\
911 \\
1,146\end{array}$ & $\begin{array}{c}\% \% \\
38.6 \\
35.1\end{array}$ & $\begin{array}{c}\% \\
36.1 \\
30.1\end{array}$ & $\begin{array}{l}.944 \\
.854\end{array}$ & $0 / 0$ \\
\hline 2 & $\begin{array}{l}-14 \\
+16\end{array}$ & $\begin{array}{l}11.1 \\
11.3\end{array}$ & $\begin{array}{l}324 \\
322\end{array}$ & $\begin{array}{l}885 \\
906\end{array}$ & $\begin{array}{l}570 \\
700\end{array}$ & $\begin{array}{r}901 \\
1,088\end{array}$ & $\begin{array}{r}894 \\
1,022\end{array}$ & $\begin{array}{l}36.7 \\
35.6\end{array}$ & $\begin{array}{l}36.2 \\
31.5\end{array}$ & $\begin{array}{l}.980 \\
.885\end{array}$ & $++/ 0$ \\
\hline 3 & $\begin{array}{l}-12 \\
+20\end{array}$ & $\begin{array}{l}10.9 \\
11.1\end{array}$ & $\begin{array}{l}477 \\
358\end{array}$ & $\begin{array}{r}1,037 \\
980\end{array}$ & $\begin{array}{l}620 \\
935\end{array}$ & $\begin{array}{l}1,150 \\
1,530\end{array}$ & $\begin{array}{l}1,097 \\
1,293\end{array}$ & $\begin{array}{l}46.0 \\
39.0\end{array}$ & $\begin{array}{l}43.5 \\
27.7\end{array}$ & $\begin{array}{l}.943 \\
.710\end{array}$ & $0 /+$ \\
\hline 4 & $\begin{array}{l}-1 \\
+14\end{array}$ & $\begin{array}{l}12.7 \\
13.0\end{array}$ & $\begin{array}{l}340 \\
320\end{array}$ & $\begin{array}{r}904 \\
1,033\end{array}$ & $\begin{array}{l}636 \\
803\end{array}$ & $\begin{array}{l}1,020 \\
1,163\end{array}$ & $\begin{array}{r}976 \\
1,123\end{array}$ & $\begin{array}{l}37.6 \\
31.0\end{array}$ & $\begin{array}{l}34.8 \\
28.5\end{array}$ & $\begin{array}{l}.925 \\
.917\end{array}$ & $0 / 0$ \\
\hline 5 & $\begin{array}{l}-1 \\
+14\end{array}$ & $\begin{array}{l}17.8 \\
17.3\end{array}$ & $\begin{array}{l}556 \\
566\end{array}$ & $\begin{array}{l}1,572 \\
1,788\end{array}$ & $\begin{array}{l}1,168 \\
1,470\end{array}$ & $\begin{array}{l}1,810 \\
2,130\end{array}$ & $\begin{array}{l}1,724 \\
2,036\end{array}$ & $\begin{array}{l}35.4 \\
31.7\end{array}$ & $\begin{array}{l}32.3 \\
27.8\end{array}$ & $\begin{array}{l}.917 \\
.877\end{array}$ & $+/ 0$ \\
\hline 6 & $\begin{array}{l}-3 \\
+42\end{array}$ & $\begin{array}{l}12.3 \\
12.5\end{array}$ & $\begin{array}{l}415 \\
490\end{array}$ & $\begin{array}{l}1,000 \\
1,311\end{array}$ & $\begin{array}{l}705 \\
970\end{array}$ & $\begin{array}{l}1,205 \\
1,550\end{array}$ & $\begin{array}{l}1,120 \\
1,460\end{array}$ & $\begin{array}{l}41.5 \\
37.4\end{array}$ & $\begin{array}{l}37.0 \\
33.5\end{array}$ & $\begin{array}{l}.892 \\
.892\end{array}$ & $0 / 0$ \\
\hline 7 & $\begin{array}{l}-3 \\
+42\end{array}$ & $\begin{array}{l}14.8 \\
15.5\end{array}$ & $\begin{array}{l}652 \\
565\end{array}$ & $\begin{array}{l}1,265 \\
1,342\end{array}$ & $\begin{array}{r}837 \\
1,137\end{array}$ & $\begin{array}{l}1,727 \\
1,964\end{array}$ & $\begin{array}{l}1,489 \\
1,702\end{array}$ & $\begin{array}{l}51.6 \\
42.1\end{array}$ & $\begin{array}{l}43.7 \\
33.2\end{array}$ & $\begin{array}{l}.847 \\
.786\end{array}$ & $+/ t$ \\
\hline $\begin{array}{c}\text { Mean } \\
\Delta \\
\mathbf{p}\end{array}$ & $\begin{array}{l}-6 \\
+26\end{array}$ & $\begin{array}{l}13.1 \\
13.2\end{array}$ & $\begin{array}{r}442 \\
424 \\
-18 \\
0.5\end{array}$ & $\begin{array}{r}1,073 \\
1,192 \\
+119 \\
0.05\end{array}$ & $\begin{array}{r}731 \\
973 \\
+242 \\
0.01\end{array}$ & $\begin{array}{r}1,251 \\
1,518 \\
+267 \\
0.01\end{array}$ & $\begin{array}{r}1,173 \\
1,397 \\
+224 \\
0.01\end{array}$ & $\begin{array}{r}41.1 \\
36.0 \\
-5.1 \\
0.01\end{array}$ & $\begin{array}{r}37.7 \\
30.2 \\
-7.5 \\
0.01\end{array}$ & $\begin{array}{c}.917 \\
.833 \\
-.084 \\
0.02-0.05\end{array}$ & \\
\hline
\end{tabular}

further by rapid intravenous infusions, unlike the sequence of events in normal animals (8). Four animals developed edema of the hind limbs or ascites. In two the ability to excrete a load of hypertonic saline was measured and found to be impaired. Digitalization did not increase cardiac output acutely nor did it produce a significant diuresis. Bacterial endocarditis (9) was not found in these animals. Hemodynamic data will be reported elsewhere in detail (10).

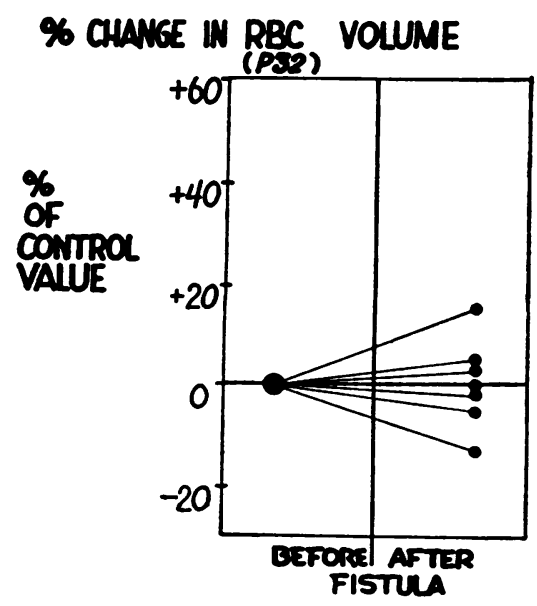

Figure 1.
It should be noted that these fistulas were much larger in proportion to body size than those usually seen clinically.

\section{Total red cell volume (Figure 1)}

After an arteriovenous fistula there was no consistent change in total red cell volume measured with radioactive red cells. The average change was $-18 \mathrm{cc}$., with variations from -119 cc. to +75 cc.

\section{Plasma volume (Figure 2)}

In contrast to the relative constancy of red cell volume, the volume of distribution of T-1824 expanded markedly in every instance, and by an average of 242 cc., or 32 per cent. That this reflected, at least in part, an actual increase in plasma volume following creation of an arteriovenous fistula is suggested by an average fall in arterial hematocrit of five millimeters, in the presence of an unchanged total red cell volume. In this small series, no correlation was apparent between the presence or absence of ascites or pitting edema and the degree of expansion of the plasma volume.

There were no consistent differences between 


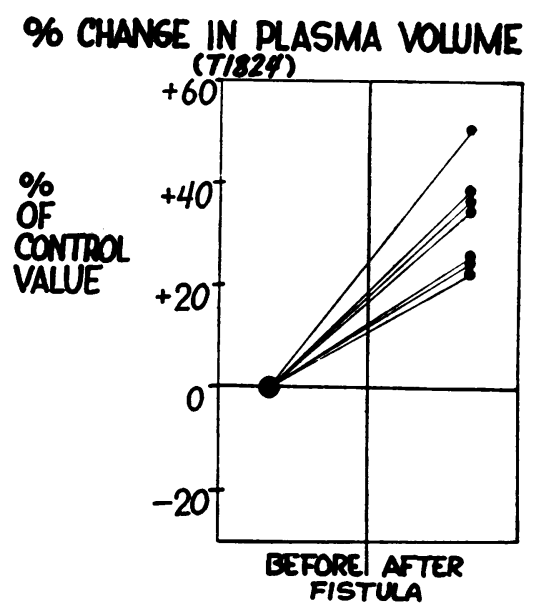

Figure 2.

the slopes of disappearance of T-1824 in normal dogs and in the same dogs after creation of a fistula. Blue dye was not detected in samples of ascitic fluid removed 30 minutes after intravenous injection of the dye.

\section{Total blood volume and total body hematocrit}

In every dog, total blood volume was increased several weeks after an arteriovenous fistula, whether this was calculated from the dilution of $\mathrm{P}^{32}$-tagged cells, from the $\mathrm{T}-1824$ space and the arterial hematocrit, or by adding the directly determined red cell volume and the T-1824 space. This was a result of the increase in the volume of plasma. As others have noted (4), values for blood volume calculated from the dilution of blue dye were invariably higher than those obtained by the red cell technique. Furthermore, the expan-

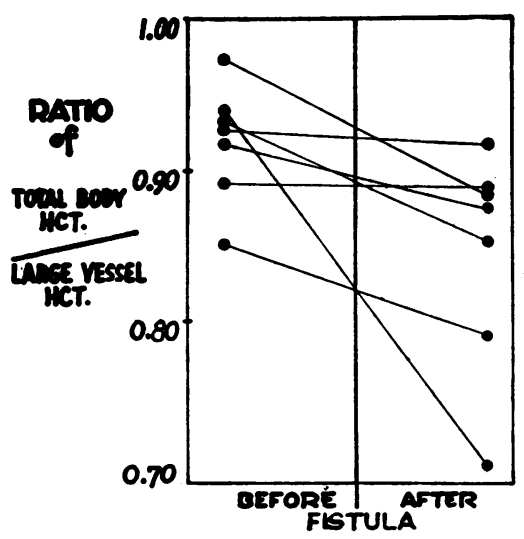

Figure 3. sion of blood and plasma volume after a fistula was significantly greater, both absolutely and percentagewise, when measured with $\mathrm{T}-1824$, than when calculated from the directly measured, unchanged red cell volume and the fall in arterial hematocrit. Another way to express this is as a decrease in the ratio of total body hematocrit to arterial hematocrit. As seen in Figure 3, this ratio diminished in six of seven instances.

\section{DISCUSSION}

The sudden direct transmission of arterial pressure to the distensible great veins which occurs when an arteriovenous fistula is opened must increase the volume of blood contained in the venous tree, with simultaneous contraction of other portions of the vascular system. A progressive increase in total blood volume under these circumstances would mitigate the necessity for such a localized vascular contraction. In 1924, Holman reported that the volume of distribution of protein-bound dyes was increased in the presence of an arteriovenous fistula (11). Although these findings were confirmed in certain subsequent studies (12-16), they were not supported by others $(17,18)$. Warren, Elkin, and Nickerson reported that less than half of forty-one patients with an arteriovenous fistula had a significant fall in blood volume estimated from the T-1824 space following surgical repair of the defect (19). On the other hand, Schreiner, Freinkel, Athens, and Stone found a post-operative decrease in T-1824 space of more than five per cent in sixteen of nineteen patients studied, although no change in hematocrit was noted (20). Lillehei, Bobb, and Visscher found a marked increase in both T-1824 space and thiocyanate space after formation of an arteriovenous fistula in dogs (21).

Although total blood volume increased in every animal in the present study after creation of a fistula, this was accomplished chiefly by an expansion of the volume of plasma, without consistent changes in total red cell volume. Plasma volume increased despite an elevation in venous (and presumably capillary) pressure which would favor increased transudation of fluid out of the vascular system. Renal retention of salt and water, stimulated, perhaps, by inadequate arterial filling $(2,3)$, presumably plays an important role 
in the expansion of extracellular fluid and plasma which occurs under these circumstances. Mobilization of extravascular depots of protein may also play a part in establishing and maintaining the expanded plasma volume $(20,22)$.

The T-1824 space in five animals with fistulas enlarged to a greater extent then would have been predicted from the concomitant fall in arterial hematocrit, resulting in a decrease in the ratio total body hematocrit : arterial hematocrit. A similar decrease in this ratio is characteristic of patients with elevated venous pressure and edema secondary to congestive heart failure (23). A1though interpretation of this finding may be difficult in the dog with intact spleen (24), three possible explanations might be suggested. First, it is possible that in a dog with a large fistula, the splenic reservoir of blood rich in red cells may contract and become smaller. Secondly, the decreased ratio might reflect a redistribution of blood between large and small vessels. This would require a larger proportion of blood to be contained in small vessels with low hematocrit in the animal with a fistula, in the face of obviously increasing engorgement of the great central veins. Finally, it is well known that protein tagged with Evans Blue dye circulates through perivascular lymph channels and extravascular protein depots, as well as inside the vascular system (25). It is conceivable that with the widened pulse pressure, elevated venous pressure and heightened rapidity of the circulation consequent to an arteriovenous fistula, the initial passage of dye into lymph channels or other easily accessible extravascular compartments might be somewhat accelerated and its calculated initial volume of distribution therefore expanded. The present experiments are consistent with such a supposition though they provide no direct evidence for it.

\section{SUM MARY}

Blood volume was measured in seven dogs, using $\mathrm{P}^{32}$-tagged red cells and $\mathrm{T}-1824$, before and up to six weeks after a large fistula was created between the aorta and inferior vena cava. The following were noted:

1. No change in total red cell volume.

2. An expanded plasma volume, reflected in a lowered hematocrit and an increase in the volume of distribution of T-1824.
3. A decrease in the ratio of total body hematocrit to the hematocrit of arterial blood.

\section{REFERENCES}

1. Cohen, S. M., Edholm, O. G., Howarth, S., McMichael, J., and Sharpey-Schafer, E. P., Cardiac output and peripheral bloodflow in arteriovenous aneurysm. Clin. Sc., 1948, 7, 35.

2. Epstein, F. H., Shadle, O. W., Ferguson, T. B., and McDowell, M. E., Cardiac output and intracardiac pressures in patients with arteriovenous fistulas. J. Clin. Invest., 1953, 32, 543.

3. Epstein, F. H., Post, R. S., and McDowell, M., The effect of an arteriovenous fistula on renal hemodynamics and electrolyte excretion. J. Clin. Invest., 1953, 32, 233.

4. Gregersen, M. I., Blood volume. Ann. Rev. Physiol., 1951, 13, 397.

5. Peters, J. P., The role of sodium in the production of edema. New England J. Med., 1948, 239, 353.

6. Ross, J. F., Chodos, R. B., Baker, W. H., and Freis, E. D., The blood volume in congestive heart failure. Tr. A. Am. Physicians, 1952, 65, 75.

7. Reeve, E. B., and Veall, N., A simplified method for the determination of circulating red-cell volume with radioactive phosphorus. J. Physiol., 1949, 108, 12.

8. Ferguson, T. B., Shadle, O. W., and Gregg, D. E., Effect of blood and saline infusion on ventricular end diastolic pressure, stroke work, stroke volume and cardiac output in the open and closed chest dog. Circulation Research, 1953, 1, 62.

9. Lillehei, C. W., Bobb, J. R. R., and Visscher, M. B., Occurrence of endocarditis with valvular deformities in dogs with arteriovenous fistulae. Proc. Soc. Exper. Biol. \& Med., 1950, 75, 9.

10. Ferguson, T. B., Gregg, D. E., and Shadle, O. W., Effect of blood and saline infusion on cardiac performance in normal dogs and dogs with arteriovenous fistulas. Circulation Research, 1954, 2, 565.

11. Holman, E., Experimental studies in arteriovenous fistulas. I. Blood volume variations. Arch. Surg., 1924, 9, 822.

12. Holman, E., Arteriovenous aneurysm in Abnormal Communications between the Arterial and Venous Circulations. New York, Macmillan Co., 1937.

13. Holman, E., Clinical and experimental observations on arteriovenous fistulae. Ann. Surg., 1940, 112, 840.

14. Rowntree, L. G., and Brown, G. E., The Volume of the Blood and Plasma in Health and Disease. Philadelphia, W. B. Saunders Co., 1929.

15. Kennedy, J. A., and Burwell, C. S., Measurements of the circulation in a patient with multiple arteriovenous connections. Am. Heart J., 1944, 28, 133. 
16. Roscoe, M. H., and Donaldson, G. M. M., The effect of arteriovenous aneurysms on blood volume and blood picture. Edinburgh M. J., 1946, 53, 391.

17. Reid, M. R., and McGuire, J., Arteriovenous aneurysms. Ann. Surg., 1938, 108, 643.

18. Ellis, L. B., and Weiss, S., The local and systemic effects of arterio-venous fistula on the circulation in man. Am. Heart J., 1929, 5, 635.

19. Warren, J. V., Elkin, D. C., and Nickerson, J. L., The blood volume in patients with arteriovenous fistulas. J. Clin. Invest., 1951, 30, 220.

20. Schreiner, G. E., Freinkel, N., Athens, J. W., and Stone, W., Dynamics of T-1824 distribution in patients with traumatic arteriovenous fistulas. Circulation Research, 1953, 1, 548.

21. Lillehei, C. W., Bobb, J. R. R., and Visscher, M. B., Effect of arteriovenous fistulas upon pulmonary arterial pressure, cardiac index, blood volume, and the extracellular fluid space. American College of
Surgeons. Surg. Forum, 1950. Philadelphia, W. B. Saunders, 1951, p. 275.

22. Schreiner, G. E., Mobilizable protein in normal subjects and in patients with traumatic arteriovenous fistulas. Clin. Research Proc., 1954, 2, 119.

23. Schreiber, S. S., Bauman, A., Yalow, R. S., and Berson, S. A., Blood volume alterations in congestive heart failure. J. Clin. Invest., 1954, 33, 578.

24. Reeve, E. B., Gregersen, M. I., Allen, T. H., and Sear, H., Distribution of cells and plasma in the normal and splenectomized dog and its influence on blood volume estimates with $P_{82}$ and $T-1824$. Am. J. Physiol., 1953, 175, 195.

25. Ferrebee, J. W., Leigh, O. C., and Berliner, R. W., Passage of the blue dye, T-1824, from the blood stream into the lymph. Proc. Soc. Exper. Biol. \& Med., 1941, 46, 549. 